UDC 930(477)(092)“18/19"

DOI 10.24919/2519-058X.20.240046

\title{
Vitalii TELVAK
}

PhD hab. (History), Professor at Department of World History and Special Historical Disciplines, Ivan Franko Drohobych State Pedagogical University, 24 Ivan Franko Street, Drohobych, Ukraine, postal code 82100 (telvak1@yahoo.com)

ORCID: 0000-0002-2445-968X

\section{Oksana SALATA}

PhD hab. (History), Professor, Head of the Department of History of Ukraine Borys Hrinchenko Kyiv University, 18/2 Boulevard-Kudryavskaya Street, Kyiv, Ukraine, postal code04053 (o.salata@kubg.edu.ua)

ORCID: 0000-0003-2498-1483

\section{Віталій ТЕЛЬВАК}

доктор історичних наук, професор кафедри всесвітньої історії та спеціальних історичних дисииплін Дрогобицького державного педагогічного університету, вул. Івана Франка, 24, м. Дрогобич, Украӥна, індекс 82100 (telvak1@yahoo.com)

\section{Оксана САЛАТА}

доктор історичних наук, професор, завідувач кафедри історії Украӥни Київського університету імені Бориса Грінченка, вул. Бульварно-Кудрявська, 18/2, м. Київ, Україна, індекс04053 (o.salata@kubg.edu.иa)

Bibliographic Description of the Article: Telvak, V. \& Salata, O. (2021). Reception of Hrushevsky Studies: Epistolary Aspect. Skhidnoievropeiskyi Istorychnyi Visnyk [East European Historical Bulletin], 20, 31-38. doi: 10.24919/2519-058X.20.240046

\section{RECEPTION OF HRUSHEVSKY STUDIES: EPISTOLARY ASPECT}

\begin{abstract}
The purpose of the research is to elucidate the heuristic potential of epistolary materials to recreate the reception of $M$. Hrushevsky's scientific works by his contemporaries. The methodological basis of the research is an interdisciplinary approach. The approach emphasises structural and functional systematic analysis of historiographical facts, comparative and historical methods based on objectivity and historicism principles. In the research periodisation, classification and typologisationmethods have been used. The novelty of the study consists in the comprehensive analysis of the epistolary aspect of receptionof M. Hrushevsky studies. The Conclusions. The research has convincingly proved the particular importance of the epistolary documents for the recreation of the reception of $M$. Hrushevsky. It has been confirmed that due to the prevalence of correspondence as a communicative practice at that time, letters represent a more comprehensive range of evaluative interpretations of M. Hrushevsky's works comparing to critical reviews of his works. Moreover, the epistolary materials help discover "private" reviewers who, for various reasons, did not publish their impressions. Among them, we have found both well-known Ukrainian intellectuals and their Russian and Western colleagues. Epistolary evidence has also helped clarify the differences between public criticism and private assessments, the particularities of popular reception, and discover original historiographical observations that have never become public. Finally, the correspondence proves that
\end{abstract}


M. Hrushevsky searched for reviewers of his works actively and reproduces M. Hrushevsky's attitude to the discussions of his previously unknown texts. This evidence calls for a more intensive and coordinated search for new epistolary sources and draws more attention to the collections known nowadays.

Key words: M. Hrushevsky, epistolary documents, reception, historical thought of the end of the XIXth - the first third of the XXth century.

\title{
РЕЦЕПТИВНА ГРУШЕВСЬКІАНА: ЕПІСТОЛЯРНИЙ ВИМІР
}

\begin{abstract}
Анотація. Мета дослідження полягає у з'ясуванні евристичного потенціалу епістолярію для відтворення рещепиії творчої спадщини М. Грушевського в інтелектуальному просторі його доби. Методологічне підгрунтя роботи становить міждисциплінарний підхід. Особливий акиент зроблено на структурно-функиіональному системному аналізі історіографічних фактів $i$ порівняльно-історичному методі, виходячи принципів об 'єктивності та історизму. Удослідженні було також використано методи періодизації, класифікації і типологізації. Наукова новизна статті полягає у спробі комплексного аналізу епістолярного виміру рецептивної грушевськіани. Висновки. Проведене дослідження переконливо засвідчило особливу вагомість епістолярію для відтворення рецепиії різнопланової діяльності М. Грушевського. Доведено, що, завдячуючи тогочасній потиреності листування як комунікативної практики, ми можемо виявити значно ииршу палітру оцінних інтерпретацій творчості українського історика, порівняно з відомими нам оцінками, щзо прозвучали в опублікованих критичних оглядах його прачь. Водночас вивчення епістолярію історика та його сучасників дає можливість окреслити коло "нереалізованих" рецензентів, котрі з різних причин так $і$ не формалізували свої читацькі враження у друкованій формі. Виявилося, що до них належали як знані українські інтелектуали, так $і$ їхні російські та західні колеги. Також саме епістолярій уможливлюе з'ясування відмінностей між публічною критикою та приватними оцінками, специфіки популярної рецепції і виявлення оригінальних історіографічних спостережень, що так і не стали надбанням широкої публіки. Зрештою, листування М. Грушевського доводить його активну позицію у пошуку рецензентів для свойх пращь та відтворює незнане з іниих джерел ставлення вченого до дискусій, викликаних його текстами. Все ие помітно актуалізує як більш інтенсивний і скоординований пошук нових епістолярних джерел, так і більшу увагу до відомих сьогодні колекиій.
\end{abstract}

Ключові слова: М. Грушевський, епістолярій, рецепція, історична думка кіния XIX периої третини $X X \mathrm{~cm}$.

The Problem Statement. The problem of the reception of Mykhailo Hrushevsky's multifaceted activity remains popular among researchers of his work over the last thirty years. The research aims at overcoming the established stereotype in the historiographical tradition of the twentieth-century that a prominent historian, like other Ukrainian intellectuals, seemed to create his texts exclusively "for domestic use". Intensive studies in recent decades have debunked the stereotype, gradually reproducing the reception of M. Hrushevsky's ideas in the Russian, Polish, Czech, German, Romanian, French and other intellectual circles. The active search work discovered and processed various texts in many languages: reviews, polemical notes, analytical articles, and anniversary posts. However, these texts mainly reproduce the academic dimension of reception of M. Hrushevsky, somewhat formalized by the genre and academic ethics requirements.

At the same time, researchers have repeatedly noted the fruitfulness of involving the extensive epistolary of M. Hrushevsky and his correspondents to clarify the complex palette of features of the reception of the intellectual heritage of the Ukrainian historian. There fore, to this day, correspondence has been involved in numerous studies, but mainly as an auxiliary illustrative source, to better understand the specifics of interpersonal communication and the context of publicly expressed assessments. However, careful study of M. Hrushevsky's 
epistolary allows us to talk about its independent heuristic value to understand receptive issues. For example, the letters often raise professional issues that did not appear in the published texts. In some cases, these letters uncover evaluations of M. Hrushevsky's works that were not printed, although several scholars intended to publish their reviews. Therefore, the discovery of epistolary sources significantly expands our awareness of how different intellectuals recepted M. Hrushevsky's ideas. We want to draw the attention of our colleagues to this currently underestimated dimension of the reception of M. Hrushevsky studies. To comprehend the multifaceted nature of the whole problem, we will summarise its main aspects below.

The Analysis of Recent Reesearches. Nowadays, there are many works devoted explicitly to either elucidating the heuristic potential of M. Hrushevsky's correspondence or the reception of his diverse activities. L. Vynar, I. Hyrych, S. Pankova, V. Telvak and other researchers have repeatedly emphasized the fruitfulness of the involvement of the epistolary in studying M. Hrushevsky's life at the end of the late nineteenth - the first third of the twentieth century. However, there is no thorough analysis of the specifics of the epistolary component of the receptive M. Hrushevsky studies nowadays, which determines the relevance of our study.

The purpose of the article is to elucidate the heuristic potential of epistolary documents for reproducing the peculiarities of the reception of M. Hrushevsky's creative heritage in the intellectual space of his time.

The Main Material Statement. Primarily, let us reconstruct the Ukrainian component of the circle of potential reviewers of M. Hrushevsky's works, who never formalized their impressions in a printed form. As far as we can judge by available sources, the Ukrainians were the largest group among historian's admirers. Their letters reveal that among the reasons why they did not publish their reflections was fear to appear incompetent. To illustrate, here is an excerpt from a letter from LarysaStarytska-Chernyakhivska to Lviv professor. Sharing her impressions of the "Illustrated History of Ukraine", she wrote: "I read your book with delight and I would like to write about it, but I'm afraid to "dare"' (Zaruba, 2013, p. 508).

Overall, many Ukrainian intellectuals expressed their impressions of M. Hrushevsky's work in the letters exclusively due to several circumstances. Most often, M. Hrushevsky's correspondents wished to express gratitude after receiving a book by the Ukrainian historian as a gift and reading it. Such a situation implied conveying a positive impression of the new work, and a correspondent did not always intend to publish what was said. Many well-known Ukrainian intellectuals (M. Kotsiubynsky, E. Chykalenko, V. Lypynsky, O. Lototsky, and many others) expressed rather unusual observations, well worth of public articulation, in such letters of gratitude to M. Hrushevsky. For example, M. Hrushevsky's teacher Volodymyr Antonovych, after reading the first monographic work of his student, wrote: "I was especially attracted by two aspects in your work, which I consider to be your great achievement. One is an indication of the existence of the Zemstvo boyars in Kyiv and the second is the hypothesis of the absence of princes after the Mongol invasion" (Nazarenko, 1991 - 1992, p. 399). Let us note that the public reflections of the founder of the Kyiv school of documentarians on "Essay on the History of the Kiev land from the death of Yaroslav to the end of the XIVth century" never appeared in print.

Several Ukrainian colleagues included critical remarks together with praise in letters. The reason for keeping these remarks secret was to preserve M. Hrushevsky's reputation as the historian (at least until the Hetman coup) remained one of the prominent symbols of Ukraine alongside Shevchenko and Drahomanov. For example, Sergiy Yefremov in his review of "Essay on the History of the Ukrainian people" mentioned: "In my opinion, in the 
new edition of "Essay" it would be great to include some additions, especially in the last part (the XIXth century) [...]. As it is now, it is quite unclear how the total "bankruptcy" of the Ukrainian people in the XVIIIth century transformed into a strong movement with future prospects. This gap needs to be filled. And the part before the Cossack movements is a bit too long, can it be shortened? Then the readers would read the book with bigger interest" (Correspondence, 2006, pp. 221-222).

Interestingly, it was the language of M. Hrushevsky's works that suffered the most substantial criticism. We know that Ivan Franko was the first to announce his critical remarks towards M. Hrushevsky's linguistic choices publicly. However, the epistolary sources allow us to claim that this kind of criticism was expressed long before that at the end of the XIXth century. Myron Korduba was the first to note gently the issues with the linguistic style of the historian. At that time, M. Hrushevsky was not content that M. Korduba ignored his insistent advice to send him the text for editing before publishing. Then, M. Korduba, though slightly arrogantly, answered: "[...] When it comes to language, one can notice that you do not use purely Rus forms of words either" (Kupchyncky, 2016, p. 164). Since that time, benevolent criticism of M.Hrushevsky's linguistic style was more frequent and relevant.

Additionally, the letters to M. Hrushevsky are sometimes the only source that helps us get more insight into the opinions of his contemporaries who did not write to M. Hrushevsky directly. Those reviews were delivered by M. Hrushevsky's students, who were proud to relay their appreciations in letters to their mentor. Notably, Ivan Dzhydzhora, the most loyal M. Hrushevsky's student, delivered the whole collection of different opinions. While in Kharkiv, he wrote to Lviv: "I attended two lectures of Bagaliy at the university when he had a lecture about "South Rus History" and discussed various theories and views on the uprising, etc., of the Cossacks. He spoke in the superlatives about Professor, calling "History" (it was the last volume) "monumental" and "classical", and called Professor, among other things, "a Benedictine (!) of our time" (Correspondence, 2008, p. 211). As the evidence shows, Bagaliy, in his printed review, was much more restrained (Telvak, 2010). Mykola Zalizniak, another student of the Lviv school, also relayed the respectful reception of his work among local intellectuals to his mentor during his wanderings in Western Europe. Thus, from his letters, we learn that such prominent figures of the German science of the time as Karl Lamprecht and Otto Getch spoke with great respect about the "History of Ukraine-Rus" (CSHAUK, f. 1235, d. 1, c. 485, p. 118).

We also get invaluable insight from the epistolary of the Ukrainian intellectuals to other parties at the end of the XIXth - the first third of the XXth century that also contained evaluations of M. Hrushevsky's works. Sometimes, the authors of such observations were noticeably more critical in their letters than in public speeches regarding M. Hrushevsky's historiographical proposals. Here we can even note a certain evaluative dissonance between public statements and epistolary reflections. An eloquent example is Stepan Tomashivsky, known for his numerous reviews of his mentor's works, in which he demonstrated their national importance and professional excellence in various ways (Telvak, 2013).Instead, in private communication, criticism outweighed approval. The ideological opponent of Lviv professor Volodymyr Mylkovych was the first to point out such insincerity. In the heat of the controversy with M. Hrushevsky's student, who selflessly defended the teacher against Mylkovych's sharp criticism, he openly stated: "In the end, there are witnesses to Mr. Tomashivsky, that he himself once said: 'prof. Hrushevsky sometimes tells such nonsense athis lectures that it is unbearable to listen"” (Milkovych, 1908). Later, the truthfulness of V. Milkovych's accusations was confirmed by Mykhailo Pavlyk (Telvak, 2008, p. 152). 
Another example is correspondence between adherents of statehood historiosophy who, in private, bluntly claimed that M. Hrushevsky's works wereoutdated, though they considerably alleviated their criticism in public (Lysty, 1976, pp. 23, 27). There are many more similar occurrences among M. Hrushevsky' critics. Overall, the issue of private discussions of M. Hrushevsky's activity in the Ukrainian intellectual environment has promising prospects for M. Hrushevsky's studies and the scholars should give it some consideration in their research.

The letters provide unique information about the reception of M. Hrushevsky's historical texts by a wider audience - another important but a little-known aspect of receptive historiography. The majority of the well-known reflections ordinary readers are preserved in grateful epistolary appeals to the author himself or the publishers who distributed his works. However, Olha Andrievska, in her first experience of reconstructing this problem, demonstrated the importance and fruitfulness of addressing impressions that were preserved in private letters (Andrievska, 2008 - 2009).

As for the non-Ukrainian readers, today, we know only about the epistolary reception of M. Hrushevsky's colleagues from the academic environment. Primarily, let us mention the "private" reviewers of the Ukrainian historian. Most of them were his Russian colleagues, given the extensive contacts of the author of "History of Ukraine-Rus" in the Russian intellectual world. For example, we can read a lot of evaluative reflections in Oleksiy Shakhmatov's letters to M. Hrushevsky. Having received as a gift the Russian translation of the first volume of the "History of Ukraine-Rus", Shakhmatov wrote: "I am most pleased with the Russian translation of the first volume of your History. Its appearance will be a major event in our historical literature" (Makarov, 1996, p. 98). Another good example is the letters of Oleksandr Lappo-Danilevsky to a Lviv professor. In one of them, the Russian historian writes about his impressions of the "Essay on the History of the Ukrainian People": "I have not yet thanked you for your book, which I have read with pleasure and interest; we still have few such scientific investigations" (Matyash, 2002, p. 139). As we know, these iconic Russian intellectuals, although well acquainted with the work of their Ukrainian counterpart, did not prepare any review of his research, so their letters are the only evidence of the reception of M. Hrushevsky's work.

Another quite promising aspect for M. Hrushevsky studies is finding out the assessments of "History of Ukraine-Rus" in the correspondence between the Russian intellectuals. We can, with a high degree of probability, predict the frequent presence of M. Hrushevsky's name in the epistolary of the Russian scholars, as he noticeably irritated or excited both fellow humanitarians and leading political activists. The well-known single mentions fully confirm such expectations. For example, let us recall how several Russian scientists evaluated M. Hrushevsky's works in the letters to the President of the St. Petersburg Academy of Sciences Prince Konstantin Romanov, written to alleviate M. Hrushevsky's situation after his arrest in 1914. Sergei Platonov wrote: "Mykhailo Hrushevsky has a great scientific talent and, regardless of his "theories", he has done a lot for historical science" (Eletsky, 1998, p. 218). O. Shakhmatov also wrote to the mentioned addressee in the same respectful tone: "[...] The critical apparatus of his eight-volume history is classical and the only one after Karamzin" (Eletsky, 1998, p. 222). These assessments primarily reflect the desire to show the protégé in a favourable light, but these observations show the similarity of assessments voiced by these Russian intellectuals at the end of the nineteenth and the beginning of the twentieth centuries.

Currently, we have little epistolary evidence of any evaluations by M. Hrushevsky's Western European colleagues. However, we can confidently highlight the considerable informativeness of the letters to the Ukrainian scientist for a more panoramic understanding of the reception of 
his ideas. For example, let us mention the letters of the prominent Czech Slavist Jan Paisker to M. Hrushevsky (Telvak, \& Radchenko, 2021). They inform us about scholar's reception of historiographical ideas, which were set out in the German translation of the first volume of "History of Ukraine-Rus". In his first letter to M. Hrushevsky, he wrote: "Let me express my sincere gratitude to you from my hospital bed for the extremely valuable insights I gained from your fundamental work in German translation and hope to gain more as long as I can hold a pen in my hand. I read it word for word carefully and with interest and admire your diligence, insight, prudence, realism, even in opinions I do not share". Additionally, J. Paisker's letters suggest that he prepared a critical response to the "History of Ukraine-Rus": "I am happy to write a review, I leave the choice of the magazine to you and ask only for a postponement, because now I'm sick and overworked". No such review has been found, which encourages a careful search of the pages of Western professional journals of that time.

It would be exciting to recreate the reception of M. Hrushevsky's ideas in the epistolary of the European intellectuals of that time, just as we have shown by the example of the Ukrainian and Russian colleagues of the Ukrainian historian. Unfortunately, this problem is virtually unnoticed currently. To illustrate the importance of this aspect, let us mention the specifics of the Polish epistolary reception of M. Hrushevsky's various activities. As we know, his colleagues from the academic environment, in general, paid tribute to the diligence and research talent of the author of "History of Ukraine-Rus" (Telvak, 2004 - 2005). Instead, they were noticeably more critical in their letters, where they even suspected M. Hrushevsky of collaborating with the Russian government. The evidence is a letter from Shimon Askenazi to Ludwik Finkle, written from St. Petersburg. As he was in St. Petersburg at the same time as M. Hrushevsky, the Polish professor wrote: "Accidentally I discovered that M. Hrushevsky was in St. Petersburg with me at the same time; I know that he takes care of the publication of his popular Russian history of Ukraine; and that he is still active. Whom he really serves, God knows better" (Hoszowska, 2013, p. 251).

The study of epistolary allows us to reproduce the peculiarities of writing reviews on M. Hrushevsky's works. The letters of the scientist allow revealing his active position in the search of appropriate reviewers. After the first volume of the "History of UkraineRus" appeared, M. Hrushevsky sent it to the editor-in-chief of the "Věstnik Slovanskỳch Starožytnosti" magazine with a request to inform the European public about the novelty of the Ukrainian studies. In response, Lubor Niederle asked the author himself to suggest the name of a possible reviewer (Naulko, 2006, pp. 634-635). He drew the Czech colleague's attention to his talented student M. Korduba. As a result, the first critical response to the "History of Ukraine-Rus" appeared, which acquainted the Western academic community with the emergence of the Ukrainian historiography on new problematic and thematic frontiers.

M. Hrushevsky's epistolary also clarifies scholar's attitude to the discussion of his works. For example, let us recall a letter to O. Lappo-Danilevsky. He expressed his reflections on the considerable interest of Western Slavists in the German translation of the first volume of the "History of Ukraine-Rus". Influenced by a lively, often polemical, but generally benevolent reception, the author wrote to the Russian colleague: "My first volume of "History", published last year in German, is now undergoing a baptism of fire. Sure, there are some sharp antics dictated by hostility to my "innovations", some reviewers settle political or personal grievances, but I was pleased to see that even the most hostile critics did not point out any real shortcomings in my conclusions or method; from this point of view, these unfriendly responses should probably be valued even higher than benevolent, especially unsubstantiated compliments" (Telvak, 2016, p. 330). 
Finally, epistolary informs about those critical reviews scattered in the pages of many small-circulation periodicals of the time. Readers of M. Hrushevsky's works often told in their letters to the scholar about the reviews published or submitted to the editors of magazines. As an example, here is an excerpt from a letter from the Russian archaeologist and publicist Vasily Storozhev to Lviv professor dated on March 22, 1905: "As promised, I inform you that my reviews on your book "Essay on the History of the Ukrainian People" are published in the journals "Russkaya Mysl” (The Russian Thought), № 2, pp. 57-59, "Nauchnoye Slovo" (The Scientific Word) № 2, pp. 131-134 and "Mir Bozhyi” (God’s World), № 2, pp. 49-51" (CSHAUK, f. 1235, d. 1, c. 874, p. 9).

At M. Hrushevsky's request, the librarian of the SSS book collection Volodymyr Doroshenko conducted a unique search to find reviews of M. Hrushevsky's work. In this regard, one of his letter reports to the chairman of the Society reported the following: "I collected more than you asked for, and I would have collected even more if the Library had all the main Russian journals in the set, and unfortunately there a lot of them are missing. That is why, I couldn't collect reviews to the 2nd - 3rd edition of "Essay" because of this fact. I'm sorry I was late with the answer for a couple of days, but I wanted to give you a complete set of reviews. There was nothing to find in our Library, but I took notes while I was still in Switzerland, so I had to turn over a bunch of my notes while I found them. I did not copy reviews from the Ukrainian publications and "Kyiv Staryna". I present all the others on separate cards" (Correspondence, 2001, p. 262). We'd like to note that such information is often the only reference point for us to search.

The Conclusions. The above observations convincingly testify to the exceptional heuristic value of the epistolary documents for researchers of M. Hrushevsky's various activities reception. Thankfully, the prevalence of correspondence as a primary communicative practice at that time allows us to reproduce not only a much wider palette of evaluative interpretations of M. Hrushevsky's work, but also significantly expand the problem-thematic horizons of the receptive aspect of Hrushevsky studies. Among its most promising areas is the research of the circle of "private" reviewers, the elucidation of the conformity or non-conformity of public criticism to private assessments, as well as the identification of noteworthy historiographical observations that have never become public. All this noticeably actualizes both a more intensive and, most importantly, a coordinated search of new epistolary sources and closer attention to the collections known today. So, Ad fontes!

Acknowledgement. We express sincere gratitude to all members of the editorial board for consultations provided during the preparation of the article for printing.

Funding. The authors received no financial support for the research, authorship, and/orpublication of this article.

\section{BIBLIOGRAPHY}

Andriewsky, O. (2008 - 2009). Reading the History of Ukraine-Rus': A Note on the Popular Reception of Ukrainian History in Late Imperial Russian and Revolutionary Ukraine. Journal of Ukrainian Studies, 33-34, 45-60. [in English]

Eletskyi, P. (1998). Ssylka M. S. Hrushevskoho [Exile of M. S. Hrushevsky]. Mynuvshee: Istorycheskyi almanakh [The Past: Historical almanac], 23, 207-262. [in Russian]

Hoszowska, M. (2013). Szymon Askenazy i jego korespondencja z Ludwikiem Finklem [Szymon Askenazy and his correspondence with Ludwik Finkel]. Rzeszów: Wydawnictwo Uniwersytetu Rzeszowskiego, 387 p. [in Polish]

Kupchynskyi, O. (2016). Vzaiemne lystuvannia Mykhaila Hrushevskoho ta Myrona Korduby [Correspondence between Mykhailo Hrushevsky and Myron Korduba]. Lviv, 424 p. [in Ukrainian] 
Lystuvannia. (2001). Lystuvannia Mykhaila Hrushevskoho. T. II [Correspondence of Mykhailo Hrushevsky. Vol. II]. Kyiv-Niu-York: UIT, 411 p. [in Ukrainian]

Lystuvannia. (2006). Lystuvannia Mykhaila Hrushevskoho. T. III [Correspondence of Mykhailo Hrushevsky. Vol. III]. Kyiv-Niu-York: UIT, 718 p. [in Ukrainian]

Lystuvannia. (2008). Lystuvannia Mykhaila Hrushevskoho. T. 4: Lystuvannia Mykhaila Hrushevskoho ta Ivana Dzhydzhory [Correspondence of Mykhailo Hrushevsky. Vol. 4: Correspondence of Mykhailo Hrushevsky and Ivan Dzhydzhora]. Kyiv; Niu-York: UIT, VD "Prostir", 550 p. [in Ukrainian]

Lysty. (1976). Lysty Osypa Nazaruka do Viacheslava Lypynskoho / LypynskyiV. Arkhiv. T. 7 [Letters of Osip Nazaruk to Vyacheslav Lypynsky / Lypynsky V. Archive. Vol. 7]. Filiadelfiia, 532 p. [in Ukrainian]

Makarov, V. I. (1996). Lystuvannia M. S. Hrushevskoho y O. O. Shakhmatova [Correspondence between M. S. Hrushevsky and O. O. Shakhmatov]. Ukrainskyi istorychnyi zhurnal [Ukrainian historical journal], 5, 89-106. [inUkrainian]

Matiash, Y. B. (2002). "Proshu pryniat uverenie v sovershennom pochtenii i predannosti". Pisma A. S. Lappo-Danylevskoho M. S. Hrushevskomu. 1905 - 1914 gg. ["I ask you to accept the assurance of perfect respect and devotion. "Letters of A. S. Lappo-Danilevsky to M. S. Hrushevsky. 1905 - 1914.]. Istorycheskyi arkhiv [Historical archive], 4: Rossyia y Ukrayna XVI-XX vv., 135-151. [in Ukrainian]

Mylkovych, V. (1908). Shche odna vidpovid moim napasnykam [Another Answer to my Attackers]. Ruslan [Ruslan], 1, 4-5. [in Ukrainian]

Naulko, V. (2006). Lysty Liubora Niderle do Mykhaila Hrushevskoho [Letters of Lubor Niederle to Mykhailo Hrushevsky]. Ukrainskyi arkheohrafichnyi shchorichnyk. Novaseriia [Ukrainian Archaeographic Yearbook. Newseries], 10/11, 634-635. [in Ukrainian]

Nazarenko, B. (1991 - 1992). Lysty M. Hrushevskohodo V. Antonovycha [Letters of M. Hrushevsky to V. Antonovych]. Ukrainskyi istoryk [Ukrainian historian], 3-4 (110-111); 1-4 (112-115), 396-412. [in Ukrainian]

Telvak, V. \& Radchenko, O. (2021). Lysty Yana Paiskera do Mykhaila Hrushevskoho [Jan Paisker's Letters to Mykhailo Hrushevsky]. Visnyk Cherkaskoho universytetu. Seriia: Istorychni nauky [Bulletin of Cherkasy University. Series: Historical Sciences], 1, 32-45. [in Ukrainian]

Telvak, V. (2004-2005). Polska hrushevskiana kintsiaXIX - pochatku XXst. [Polish Hrushevsky Studies at the end of the nineteenth - beginning of the twentieth century]. Ukrainskyi istoryk [Ukrainian Historian], 3-4 / 1, 47-60. [in Ukrainian]

Telvak, V. (2008). Tvorcha spadshchyna Mykhaila Hrushevskoho v otsinkakh suchasnykiv (kinets XIX - 30-ti roky XX stolittia) [Mykhailo Hrushevsky's Creative Heritage in the Estimations of Contemporaries (the end of the XIXth - the 30s of the XXth century)]. Kyiv-Drohobych: "Vymir", 494 p. [in Ukrainian]

Telvak, V. (2010). Hrushevskiana Dmytra Bahaliia [Hrushevsky Studies of Dmytro Bahaliy]. Visnyk Cherkaskoho universytetu. Seriia: Istorychni nauky [Bulletin of Cherkasy University. Series: Historical Sciences], 192, 7-14. [in Ukrainian]

Telvak, V. (2013). Mykhailo Hrushevskyi v otsinkakh svoikh uchniv (persha tretyna XXst.) [Mykhailo Hrushevsky in the Assessments of his Students (the first third of the twentieth century)]. Istoriohrafichni doslidzhennia v Ukraini [Historiographical research in Ukraine], 23, 160-197. [in Ukrainian]

Telvak, V. (2016). Lysty Mykhaila Hrushevskoho do Oleksandra Lappo-Danilevskoho [Letters of Mykhailo Hrushevsky to Oleksandr Lappo-Danilevsky]. Zapysky NTSh [Notes of SSS], 270, 313-334. [in Ukrainian]

Tsentralnyi derzhanyi istorychnyi arkhiv Ukrainy u m. Kyievi [Central State Historical Archives of Ukraine in the City of Kyiv-CSHAUK]

Zaruba, V. (2013). Lystuvannia Larysy Starytskoi-Cherniakhivskoi z Mykhailom Hrushevskym [Correspondence of Larysa Starytska-Chernyakhivska with Mykhailo Hrushevsky]. Zapysky NTSh [Notes of SSS],CCLXV, 233-252. [in Ukrainian]

The article was received November 29, 2020. Article recommended for publishing 31/08/2021. 